\title{
Analysis of socioeconomic factors in the participation of parents in the Ecuadorian educational context
}

\author{
Análisis de factores socioeconómicos en la participación de los padres \\ en el contexto educativo ecuatoriano
}

\begin{abstract}
Morayma Jimena Bustos Yépez. ${ }^{1}$, Lourdes Elizabeth Navas Franco. ${ }^{2}$ \& Fernando Sebastián Vega Buenaño. ${ }^{3}$
\end{abstract}

\begin{abstract}
Introduction. The family is the axis on which the social structure develops, and that is why exploring how they participate in the school life of children becomes, over the years, something of importance. It is necessary to know how participation develops from some of the variables that can influence it. Objetive. Contrast whether the participation of parents in school activities has something to do with schooling, occupation, gender, marital status, age of parents, region, sector, and type of support of the school in which their children study. Methodology. For this, field research of cross-sectional type, of descriptive scope, was carried out, to check the levels of relationship, among the variables of this study. Chi-square test was used with the statistical software R Project. Results. As main results, it was found that the variables schooling (2.255e-12), occupation $(9.578 \mathrm{e}-$ $13)$, gender (6.43e-15), marital status (0.04333), sector (0.0006822) and type of school support $(0.0001065)$ are related to the levels of parental participation, while the age of the parents (0.2975), and the region (0.6784) do not have significant levels of relationship. Conclusions. It is concluded in the study that the level of participation of parents in the Ecuadorian educational context is high; the variables that are related in a positive or negative way must be taken into consideration to improve the school processes that need this collaboration.
\end{abstract}

\footnotetext{
1 Universidad Tecnológica Indoamérica, Carrera de Educación Básica, Tungurahua, moraymabustos@uti.edu.ec ORCID, https://orcid.org/0000-0001-7797-7061

2 Universidad Tecnológica Indoamérica, Carrera de Educación Básica, Tungurahua, lourdesnavas@uti.edu.ec ORCID, https://orcid.org/0000-0003-4794-9099

3 Universidad Tecnológica Indoamérica, Carrera de Educación Básica, Tungurahua, fernandovega@uti.edu.ec ORCID, https://orcid.org/0000-0002-2147-986
} 
Keywords: context, school, family, parental involvement, socioeconomic variables

\section{Resumen}

Introducción, la familia es el eje sobre el cual la estructura social se desenvuelve, y es por eso que investigar como la familia participa en la vida escolar de los niños se va convirtiendo al pasar de los años en algo de importancia, es necesario conocer cómo se desarrolla la participación desde algunas de las variables que pueden influenciarla. Objetivo, relacionar si la participación de los padres en las actividades escolares tiene algo que ver con la escolaridad, ocupación, género, estado civil, edad de los padres, la región, sector y tipo de sostenimiento de la escuela en la que estudian sus hijos. Metodología, se realizó una investigación de campo de tipo transeccional de alcance descriptivo, para comprobar los niveles de relación, entre las variables de este estudio se utilizó la prueba chi cuadrado con el software estadístico R Project. Resultados, se encontró como principales resultados que las variables escolaridad (2.255e-12), ocupación (9.578e-13), género (6.43e-15), estado civil (0.04333), sector (0.0006822) y tipo de sostenimiento de la escuela (0.0001065) tienen relación con los niveles de participación de los padres, mientras que la edad de los padres (0.2975), y la región (0.6784) no tienen niveles de relación significativos. Conclusión, se concluye en el estudio que el nivel de participación de los padres en el contexto educativo ecuatoriano es alto, se deben tomar en consideración las variables que se relacionan de manera positiva o negativa para mejorar los procesos escolares que necesitan de esa colaboración conjunta.

Palabras claves: contexto, escuela, familia, participación de los padres, variables socioeconómicas

\section{Introduction}

The family is the first place where affective, emotional, cultural, and educational bonds are structured, therefore, it is considered the most important institution in the life of every being. It is the place in which social networks are transferred to the community that, considering the theory of human capital studied by Smith since the 70's, considers the family the point of conversion of all social structure.

For Martiñá (2003) the family is the group of people who live together and are united by various ties of consanguinity, affectivity, and support. In the family, in addition to providing love and security, basic principles such as food, health, protection and education are satisfied, which can to a greater or lesser degree influence throughout the life of the individual.

All those who constitute the circle of students are directly involved in the learning processes of children, have the fundamental responsibility of caring for and guiding them in the school stage, being an essential support for teachers and authorities that make up 
the school. Authors such as Varela (2014), and Chávez (2008) consider that children in the family are nourished by values, rules of conduct and principles that are reflected in society and reinforced in the school, putting into practice everything acquired, favoring harmonious coexistence and respect.

Arantzazu (2003) considers that education and the family have a fundamental relationship because they share the function of forming the person of tomorrow by making them autonomous, independent, with the ability to solve present problems with balanced thinking, establishing affective bonds according to the current situation.

For Estrada (2008) the role of parents in the life and school activities of their children is defined and directed, because they have a commitment acquired around participation in all the actions that are convened by the institution, this will positively favor them, and they will be able to make sure of the academic performance that their children are achieving. They will be able to dialogue permanently with the teacher which will allow them to know the situation inside the school (Acuña et al., 2018).

Parents are co-responsible for the instruction and academic degree that their children can achieve; the school and families must base their support on the development of values, establishing norms and rules that favor the improvement of personality. Teachers and parents must be careful in their behavior since children imitate what they see and, at an early age, it is about training them in values and that they acquire good attitudes to form critical and fair people (Chaparro, 2016).

Countless are the activities and responsibilities that parents have within educational institutions, for Enríquez et al. (2013) they must be involved in all actions that have to do with the behavior and performance of children, inquire about the educational processes, provide the materials requested by the school and by the teachers, motivate them at home to perform the tasks and activities that the teachers propose, and respect rules established by the institution.

Being the family a pillar of human development, it is not exempt from being the main part in the education of children. Several authors have tried to measure this participation and have divided it into various dimensions. In their research, Sarmiento and Zapata (2014) found that participation can be defined in 1) The involvement of the family in the learning activities of students. 2) They see it from the communication links between the family and the school given to guide. 3) The third dimension distinguishes the participation of parents in the management of the educational institution. 4) This last dimension does not only limit family-school participation but also sees this participation already at the community level, with the option of establishing much broader cooperative work alliances.

\section{Theoretical Framework}

About the participation of parents in the Ecuadorian educational context, this constitutes a basic and fundamental right because being a democratic society, it is protected by public 
powers, laws, regulations that facilitate the way to make it effective and constructive. There are numerous investigations (Sheldon \& Epstein,2005) that show that, in addition to being the responsibility of parents and families, the involvement brings benefits not only to the students but to the school itself and even to the parents themselves. For Kñallinsky (2010) the participation of families and their involvement in the institution is considered as an element of quality, the same that is measured through the management standards issued by the Ministry of Education of Ecuador.

Another important aspect that influences the involvement of parents with school occurs when parents do not have a job or activity, that is, the father or mother stops working, life and family environment changes affecting the lifestyle of the home. According to Machaca (2007) contact, participation, and relationship with the school increase, worrying more about school activities that do not have to be considered with the contribution of economic resources. Unfortunately, it is beneficial in one part, but harmful in another, noticing changes in behavior and willingness to fulfill tasks entrusted to family members. Students, in the same way, tend to acquire social-emotional problems: it is common to see them lonely, distrustful, depressed, with low self-esteem, and less ability to fulfill their obligations (Robledo and García, 2009).

As in many parts of the world, Ecuador is not exempt from this type of difficulties. According to the National Institute of Statistics and Censuses (INEC, 2011), when the so-called Socioeconomic Level Stratification Survey was applied in 5 provinces of Ecuador, it was allowed to segment into 5 strata the 9,744 households consulted, finding that $1.9 \%$ are located in stratum $\mathrm{A}, 11.2 \%$ of households consulted are placed in level B, $22.8 \%$ of the total are located in level $\mathrm{C}+, 49.3 \%$ are located in stratum $\mathrm{C}$ - and $14.9 \%$ of the sample is in level D. To determine the scores, different characteristics were selected such as housing, education, household economics, goods, technological resources, and consumption habits.

Alvarado, et. al (2019) established that, in addition to the different dimensions given by authors on family-school participation, a substantial part of this participation is the socioeconomic variable since they instituted that it has a direct impact on the levels of parental participation in the school, translated into a positive relationship because the better socioeconomic level, the better the collaboration of parents in academic activities, and therefore excellent student performance (Gamazo et al., 2018).

In the same way, authors such as Balarin and Cueto (2008) within their research report that parents with a high socioeconomic level may be more prepared to participate in the academic activities of their children. Similarly, it is established that the economic, social, and cultural resources that families possess, and their living conditions, influence this participation in different ways (Bello and Villarán, 2009).

Sandoval et al. (2017) found that the self-efficiency that parents say they have in the education of their children, has effects on participation within the home. This was 
evidenced through the invitations of teachers and the perceptions that parents have about the demands for support they say they meet when their children ask them.

For Hoffman et al. (1995) sociodemographic variables determine the development of the individual; they specifically analyzed the belonging between social class and student development. Social class is associated with the occupation of families which mainly affects beliefs, values, lifestyles, and of course the level of concern and association with the educational institution. Social class is an indicator to determine the physical environment in which the child operates, the sector in which they reside (Bustos 2021), their entertainment, access to health, food and especially the social practices of parents that produce authoritarian structures and, of course, determine the school family relationship.

According to Gómez et al. (2014) the socio-economic aspect presents notable characteristics in terms of the participation that families have with the school. It highlights that parents who are located in a high socioeconomic level have a different treatment with the school and the student; families that are in the lower or working class generally tend to use force and, with regard to the relationship with the institution, they avoid having an approach with the school. Meanwhile, parents who are in a middle class have greater involvement in the school because they generate inductive discipline.

Huerta (2010) shows that parents and families who are in a medium socioeconomic level - where there is greater involvement with the educational institution and, therefore in the school life of their children - attend calls made by the institution, meetings organized by the parent commissions and, in general, fulfill their role and their necessary involvement. As Coleman states (1996) cited in Razeto (2016), the influence that the family has cannot only be limited to its economic level or social class, but also counts the educational support that the family provides in favor of the formation of children.

According to García (2008) at present, the social problem that has been evidenced is that the parents of the students work to bring sustenance to their home. The integration of women in the world of work has produced notable changes in families, in the learning process of students, and in participation with the educational institution. Years ago, the woman was the representative of the household that came to the institution and was related to the activities planned by the educational center. This type of factors, as well as the educational and economic level of the parents, play an important role in the degree of participation and support that is detected (Rodríguez and Guzmán 2019). Not only the employment situation of the parents affects the relationship they have with the school, but the dedication and time they share with their children is also affected. Valdés et. al (2009) found in their study that mothers are the ones who have the best knowledge of school and communicate better with their children, regardless of whether they perform functions outside the home.

In a study conducted by Machaca (2007) where they followed the families of school-age students, they showed that it is essential to keep in mind that the fact of seeking daily 
sustenance for homes should not deprive affective contact with children and, even worse, neglect their school activities or the needs denoted by educational institutions and what they seek as presence and support of families.

Other important situations that have been found by research such as that of Yurén et. al (2014) refer to the cultural capital of the family, that is, to the levels of schooling that parents have; the authors have identified that this aspect is translated into better participation and advantages of improvement for their children.

For Ruíz de Miguel (2001) the relationship between the father, mother, child, and school is vital for the development of students; body contact that is evidenced with games, caresses, hugs, benefit in the improvement of intelligence and affectivity. Maintaining a relationship with the educational institution also brings positive factors such as the impulse of responsibility in the student, the increase of their self-esteem, which influences their social success.

Ávila (2021) mentions that working will always be essential in addition to being an obligation, but this should not affect and prevent the possibility of parents relating to their children and parents with the educational institution. Llévot (2015) states that several families agree that they cannot have a greater participation in school management due to lack of time and resources. Students need to know that their parents are present in all the activities they develop.

Ruiz de Miguel (2001) states that the main family factors that are directly related to the involvement of parents in school are parents' level of schooling, the environment, family climate, cultural resources, structure, as well as the socioeconomic level of the family. In this sense, this research aimed to relate whether the participation of parents in school activities has something to do with schooling. Gender, marital status, age of parents, region, sector, and type of support of the school in which their children study, for which a transitional field research was carried out.

\section{Methodololy}

\section{Sample}

To collect the information, collaboration of the students of the bachelor's degree in basic education was possible, who contacted the parents of institutions nationwide and applied the survey with the parents who voluntarily agreed to answer it. It was sent by technological means, leaving the sample with $33 \%$ of parents from the coastal region, $40 \%$ of the Sierra region and $27 \%$ of the Amazon region.

For this research, 5538 data were collected, the same data that were in the first instance subjected to a review, due to inconsistencies detected, being the population made up by 4584 parents surveyed. This information was used to perform statistical analysis. 


\section{Instrument}

For the collection of information on parental participation in school, the survey validated by Valdés, A. et.al (2009) was used, who carried out the family participation scale to evaluate the participation of parents in the activities of children related to school, based on Cronbach's alpha reliability coefficient of (0.92) and factor analysis by the varimax rotation method, which established three factors to be measured, such as Communication with the school, Communication with the child and knowledge of the school.

We proceeded to improve the measurement of the instrument for which the content validation was made, since some words of the questionnaire were changed to our context so that they are of better understanding for the people who had to answer. For the validation of the construct, an evaluation sheet was built, which was delivered to fellow teachers with a career in Ecuadorian educational teaching, reaching the conclusion that by varying those words it would be possible to reach the idea better. Once the instrument was designed and validated, the survey was applied to a pilot group belonging to the same educational context; two applications were carried out, varying between them a period of 14 days. The degree of correlation was determined, which was high with $\mathbf{0 . 9 8}$ of reliability.

The first part of the survey included questions about socioeconomic information from which the variables of this study are derived, data such as parental occupation, level of schooling, the type of school in which their children are, and age. The second section of the survey consisted of 22 items that measure parents' participation in their children's education.

\section{Method}

To carry out this research, a field study of descriptive scope was carried out, since it seeks to specify some characteristics of these variables and then, associate these variables through the relationship of the information obtained to expose the degree of dependence that exists between some socioeconomic factors and the participation of parents in the activities of their children (Hernández et. al 2010).

\section{Application and data collection}

The collection of the information was carried out with the help of 315 students of the Basic Education degree, distance modality, who in the first place were given an induction on the objective of the research; anonymity was assured in the surveys themselves that were done through the internet using Google Forms for greater ease, due to the confinement situation to which we were subjected.

\section{Data analysis}

To perform the analysis of the data, a descriptive analysis of the results was carried out initially, to detect the standard means and deviations that help us to better interpret the results obtained in the relationships between the variables. 
To obtain the results of the relationship of variables, statistical analyses were performed using the chi-square test in the statistical software $\mathrm{R}$ project version 4.0.5 (2021.03.31).

\section{Results}

This section presents the analysis of the data collected through the surveys applied to 4584 parents, to determine the relationships between the variables schooling, occupation, gender, marital status, age of the parents, the region, sector, and type of support of the school in which their children study. To present the information we proceeded first to establish the means to better understand the results shown in the following table:

Table 1

Standard means and deviations of study variables

\begin{tabular}{|c|c|c|c|c|c|}
\hline Variables & & Sample & Percentage & Median & ds \\
\hline \multirow{6}{*}{$\begin{array}{l}\text { Parents' } \\
\text { schooling }\end{array}$} & None & 48 & 1,05 & 67,13 & 14,97 \\
\hline & Basic education & 735 & 16,03 & 71,54 & 14,23 \\
\hline & High school & 1819 & 39,68 & 73,73 & 13,46 \\
\hline & $\begin{array}{l}\text { Third level - bachelor's } \\
\text { degrees and related }\end{array}$ & 1746 & 38,09 & 75,65 & 12,28 \\
\hline & Fourth level - master's & & & & \\
\hline & degrees & 236 & 5,15 & 75,88 & 12,08 \\
\hline \multirow[t]{2}{*}{ Gender } & Male & 1856 & 40,49 & 72,02 & 13,82 \\
\hline & Female & 2728 & 59,51 & 75,60 & 12,55 \\
\hline \multirow{9}{*}{$\begin{array}{l}\text { Parental } \\
\text { occupation }\end{array}$} & Worker & 132 & 2,88 & 70,18 & 16,71 \\
\hline & Artisan & 150 & 3,27 & 69,91 & 14,79 \\
\hline & Farmer & 332 & 7,24 & 70,60 & 14,01 \\
\hline & Formal trader & 299 & 6,52 & 73,28 & 14,05 \\
\hline & Informal trader & 151 & 3,29 & 71,60 & 14,74 \\
\hline & Private employee & 1141 & 24,89 & 74,17 & 12,74 \\
\hline & Public employee & 1299 & 28,34 & 75,64 & 12,20 \\
\hline & Housework & 683 & 14,90 & 75,66 & 12,53 \\
\hline & Unemployed & 404 & 8,81 & 74,09 & 13,55 \\
\hline \multirow{4}{*}{ Marital status } & Bachelor & 1343 & 29,30 & 73,73 & 13,45 \\
\hline & Married/Free Union & 2843 & 62,02 & 74,57 & 13,03 \\
\hline & Widower & 68 & 1,48 & 72,24 & 13,30 \\
\hline & Divorced & 330 & 7,20 & 72,60 & 13,49 \\
\hline \multirow{4}{*}{ Age } & From 18 to 27 years old & 881 & 19,22 & 74,62 & 13,58 \\
\hline & From 28 to 37 years old & 1987 & 43,35 & 74,62 & 12,84 \\
\hline & From 38 to 47 years old & 1239 & 27,03 & 73,39 & 13,46 \\
\hline & Age 48 and older & 430 & 9,38 & 73,75 & 12,86 \\
\hline \multirow{3}{*}{ Region } & Coast & 1505 & 32,83 & 74,67 & 13,17 \\
\hline & Saw & 1838 & 40,10 & 73,99 & 13,05 \\
\hline & Orient & 1241 & 27,07 & 73,74 & 13,44 \\
\hline \multirow{2}{*}{$\begin{array}{l}\text { Sector in which } \\
\text { you live }\end{array}$} & Urban & 3046 & 66,45 & 74,51 & 13,07 \\
\hline & Rural & 1538 & 33,55 & 73,43 & 13,43 \\
\hline
\end{tabular}


Table 1

Standard means and deviations of study variables (continuation)

\begin{tabular}{llcccc}
\hline Variables & & Sample & Percentage & Median & ds \\
\hline \multirow{2}{*}{$\begin{array}{c}\text { Type of school } \\
\text { support }\end{array}$} & Public & 3133 & 68,35 & 73,49 & 13,67 \\
& Charter & 669 & 14,59 & 75,68 & 11,52 \\
& Private & 782 & 17,06 & 75,47 & 13,10 \\
\hline
\end{tabular}

Source: data obtained from the surveys conducted with parents nationwide.

As it can be seen in Table 1, in the variable schooling of parents the average determines that parents who do not have any level of education are at the low level (67.13) in relation to the rest of the data, while it can be observed that parents with higher schooling have a high level of participation (75.88).

In the variable occupation of parents, those who participate least in the academic activities of their children are those who work as artisans (69.91), while it was detected that parents who have a job in the public sector and people who work in domestic chores, that is, take care of their home, present high levels of participation with $(75.66 ; 75.64)$ respectively.

Regarding the gender variable, the answers given by the respondents were considered, where they had as options, male, female, and others. There were only 4 answers with the option others of the 5538 surveys, for that reason these data were not considered for the present study, and we worked with the variable's fathers and mothers of family. The results of the means show that it is the mothers who participate the most in the academic activities of their children with a (75.60) over the (72.02) of the fathers.

When analyzing the variable marital status, considering whether they are single, married or in a free union, widowed or divorced, it could be noted that the parents who say they have more participation are those with married marital status or free union with (74.57), while those who participate the least are the ones who have been widowed (72.24), followed by those who are divorced (72.60).

While considering the variable age of parents, those who are between the ages of 18 to 37 years old reported having a good participation in the academic activities of their children with an average of (74.62), and the parents who participate the least are those who are at the age of 38 to 47 years (73.39).

With respect to the region where the families live, it was found that it is the parents of the coastal region who say they participate more in the activities within the school with a level of (74.67) while apparently the parents of the Amazon are the ones who participate less with a level of (73.74), and taking into account the sector, parents living in the urban area of the three regions of the country are the ones who participate most in the academic activities of their children with a level of (74.51).

Finally, the support of the educational institution was considered, and it can be said that parents who have their children in charter institutions are the ones who participate the most with a level of (75.68), while in public schools a low level is noticeable with (73.49). 
Although the general results show that in this research the average participation of the parents is $(74,15)$ that is to say, a medium high level, the differences detected in the means helped us to generate a descriptive analysis of the variables of the study and to detect that it could be influencing the relationships between the variables and the participation of the parents in the academic activities of their children.

\section{Analysis of the relationship of the study variables}

To establish the relationship between the variables, the chi-square test was performed through the statistical software R Project obtaining the following results:

For the variable schooling of the parents, a p-value of $(2,255 \mathrm{e}-12)$ was obtained with these results it can be concluded that the level of studies of the parents it is related to participation. That is, the academic preparation of parents has a lot to do with their participation in school. This result is logical since, as Yurén et al (2014) affirm, the higher the level of studies, the greater the awareness to meet the academic needs of their children.

In the case of the variable occupation of the parents, a p-value of $(9,578 \mathrm{e}-13)$ was obtained, which leads to the conclusion that the work carried out by parents is related to participation. That is, the types of work of the parents of the study have a lot to do with their participation in school. This result could be understood since, as Hoffman et al. assert (1995), the occupation of parents determines their social class, and this directly affects their participation in school. When analyzing the averages, it was detected that in the same way those who work in domestic chores (75.66) and unemployed people (74.09) present high levels of participation that, according to Machaca (2007), although such conditions do not benefit the economy of the family, usually translate into greater opportunities to get involved in the academic activities of their children.

In correspondence with the gender variable, it can be concluded, with a p-value of (6.43e15), that there is a relationship between gender and participation, that is, the observation of the table of means that places mothers as the ones who most attend to the educational needs of their children is verified. This result agrees with Valdés et. al (2009) who found that mothers had better levels of participation in the academic activities of their children, being the knowledge of school and communication the more important factors in our environment. As it can be seen in the results, the ones that most meet the needs of academic growth in are those in early ages, product of the social structure in which we live.

Analyzing the variable marital status of the parents, a p-value of (0.04333) was obtained; there is a relationship not as strong as the previous ones between the marital status of the parents and their participation in the school. Considering that, the families where the parents are married or in a free union are the ones who have answered having the greatest concern. This family structure grants a stability that is reflected in the results. As Razeto (1996) says, the influence of the family is not seen only at the economic level but also in the support they provide in their environment. 
In relation to the variable age of the parents, the result obtained in the p-value was (0.2975) which tells us that there is no relationship between the age of the parents and the levels of participation, that is, the age has nothing to do with the levels of participation. However, the results of the means indicate that parents between 18 and 37 years old are the ones who participate the most in the academic activities of their children $(74,62)$.

For the variable region in which the family lives, with a p-value of (0.6784), it is verified that there is no relationship between the regions in which the families live and the levels of participation that they claim to have in the academic activities of their children; the fact that the parents fulfill their obligations in the educational institution does not depend on the region.

Taking into account the sector in which they live - whether urban or rural - with a pvalue of (0.0006822), it is established that if there is a relationship between the sector and the participation of parents, noting in the averages that those who participate most are the parents of the urban sector (74.51) which coincides with the study of Bustos (2020) where it was found that, in the urban sector, there is greater participation; due to the different characteristics and opportunities parents become more involved in their children's academic activities.

Finally, the last variable that was considered for this article is the type of support that the school has and, with a p-value of $(0.0001065)$, it is verified that there is a relationship between the type of support of the school and the levels of participation. It has something to do with the school being public, charter or private. In the study, it is reflected through the average that in charter schools, the parents say they have more participation $(75,68)$, while the lowest level is in public schools $(73,49)$. This may be due to the socioeconomic conditions that most parents have in these schools and, as previously verified in this study, the social class, and cultural level have a lot to do with the levels of participation that parents have in their children's education.

\section{Conclusions}

- The relationships that exist between family and school are important because these can generate direct implications in the processes of learning, communication, socialization and in some cases even the educational future of children. It can be concluded that the parents of this study participate in the academic activities of their children highlighting that schooling, occupation, gender, marital status, sector, and type of support of the school have significant levels of relationship, that is, all these variables, positively or negatively, are directly related to the participation of parents in the school activities of children.

- It should be noted that it is the mothers who continue to worry a little more than the fathers about these activities. It is also verified that the higher the degree of studies there is more predisposition to academic help. The fathers who have heavy and very laborious work do not have that approach with the educational 
institution, as well as it is also seen in the study that parents who have domestic work or are unemployed manifest be more aware of their children.

- On the other hand, the age of parents, and the region in which they live, has nothing to do with parental involvement; these variables are not relevant when determining who participates most in school activities.

- In general, the level of parental participation in the Ecuadorian educational context detected is high, this may be since, as it is established by the sample, the survey was spread in an area of the population with better possibilities.

- Through the study, it is recommended to research into the issue of parental involvement by establishing mechanisms that help to better reach new relationships or variables that may be intervening in the adequate family participation. Likewise, information can be accessed from another source, that is, investigating the other educational actors and looking at participation from different angles.

\section{Bibliographic references}

Acuña, N., Concha, C., De la Fuente, B., Medina, R. (2018). ¿De qué hablamos cuando hablamos de comunicación, relación, participación, compromiso e involucramiento de las familias con la escuela? Revista Académica UCMaule, 55, 59-70. http://doi.org/10.29035/ucmaule.55.59

Alvarado, J., Ube, J., Naranjo, F. (2019) La interrelación de los factores socioeconómicos con el éxito académico universitario en el Ecuador. IV Congreso internacional virtual sobre La Educación en el Siglo XXI. 80-90 https://www.eumed.net/actas/19/educacion/8-la-interrelacion-de-los-factoressocieconomicos.pdf

Arantzazu, O. (2003). Las actuaciones voluntarias como cauce de participación social. El interés de su inclusión en el sistema educativo formal. Estudios sobre educación. ISNN $\quad 1578-7001, \quad \mathrm{~N}^{\circ}$. $\quad 5, \quad 181-190$. https://dadun.unav.edu/bitstream/10171/8528/1/Notas\%20Ne.pdf

Ávila, N., Giannotti, S. (2021). El acompañamiento familiar en los procesos educativos durante la infancia: un acercamiento a través de estudios de caso. Universidad de la Habana. $N^{\circ}$ 291. http://scielo.sld.cu/pdf/uh/n291/0253-9276-uh-291-4.pdf

Balarin, M., \& Cueto, S. (2008). La calidad de la participación de los padres de familia y el rendimiento estudiantil en las escuelas públicas peruanas. (Mclauchlan, C, Trad, GRADE; Niños del Milenio). https://www.academia.edu/4182180/La_calidad_de_la_participación_de_los_pa dres_de_familia_y_el_rendimiento_estudiantil_en_las_escuelas_públicas_perua nas

Bello, M., \& Villarán, V. (2009). Las relaciones de la escuela con la familia y la comunidad, en el camino hacia la equidad. En Néstor López (Coord.). De 
relaciones, actores y territorios: hacia nuevas políticas en torno a la educación en América Latina (pp. 115-170). Buenos Aires: IIPE; Unesco. http://escuelajuan23.com/fs_files/user_img/S.\%20Corbetta.pdf

Bustos, M. (2021). Closer look at parent involvement in their children's education: Is gender, sector (urban and rural) and parent's level of education an issue? Currículo sem Fronteiras, 21(1), 269-292. http://dx.doi.org/10.35786/16451384.v21.n1.14

Chaparro, A. (2016). Familia y rendimiento académico: configuración de perfiles estudiantiles en secundaria. Revista Electrónica de Investigación Educativa. 8(1), 53-68 http://redie.uabc.mx/redie/article/view/774

Chávez, J. (2008). Género y Familia. México: Plaza y Valdés Editores.

Enríquez, C.,Segura, A., Tovar. J. (2013). Factores de riesgo asociados a bajo rendimiento académico en escolares de Bogotá. Revista Investigaciones Andina. 15(26), 654666. ISSN 0124-8146. https://www.redalyc.org/pdf/2390/239026287004.pdf

Estrada, M. (2008). La participación social en educación: Hacia una "Comunidad escolar" en las Margaritas, Chiapas. Revista Interamericana de Educación para la Democracia. RIED - $\quad$ IJED, $1(2), \quad$ 185-204. https://dhls.hegoa.ehu.eus/uploads/resources/4839/resource_files/Participaci.pdf

Gamazo, A., Martínez-Abad, F., Olmos-Miguelanez, S., \& Rodrígez-Conde, M. (2018). Evaluación de factores relacionados con la eficacia escolar en PISA 2015. Un análisis multinivel. Revista de Educación. $N^{\circ}$ 379, 56-84. https://dialnet.unirioja.es/servlet/articulo?codigo $=6219436$

García, F. (2008). Motivar para el aprendizaje desde la actividad orientadora. Secrearia General Técnica. Ministerio de Educación y Ciencia. $\mathrm{N}^{\circ} 179$. https://sede.educacion.gob.es/publiventa/PdfServlet?pdf=VP12377.pdf\&area $=\mathrm{E}$

Gómez, V., Muñoz. C., Silva, I., Paz, M., \& Guerra, P. \&. Valenzuela, J.(2014). Creencias y oportunidades de aprendizaje en la práctica educativa en contextos de pobreza. Perfiles Educativos. 36(144), 173-188. DOI:10.1016/S0185-2698(14)70630-0

Hernández, R., Fernández, C., Baptista, M. (2010). Metodología de la Investigación. México. McGraw-Hill.

Hoffman, L., \& Paris, S. (1995). Psicología del desarrollo hoy. Madrid: McGraw-Hill. .

Huerta, E. (2010). Formas de participación parental en las escuelas secundarias mexicanas de altos y bajos resultados académicos. Revista Iberoamericana de Educación. 54, 167-185. https://doi.org/10.35362/rie540547 
Instituto Nacional de Estadísticas y Censos [INEC]. (2011). Encuesta de estratificación del Nivel Socioeconómico. https://www.ecuadorencifras.gob.ec/encuesta-deestratificacion-del-nivel-socioeconomico/

Kñallinsky, E. (2010). Familia Escuela y comunidad. Rivista Italiana di Educazione Familiare. 2, 45-56. https://core.ac.uk/download/pdf/228546189.pdf

Llévot, N., \& Bernad, O. (2015). La participación de las familias en la escuela: Factores clave. Revisa de la Asociación de Sociología de la Educación, RASE. 8(1), 57-70. https://ojs.uv.es/index.php/RASE/article/view/8761/8304

Machaca, G. (2007). La participación social en la educación en Bolivia en el contexto de la implementación de la EIB. Estudio de caso en las comunidades de Itanambikua y Tomoroco, Universidad Mayor de San Simon. PROEIB-Andes. DOI: https://doi.org/10.31391/S2007-7033(2018)0050-010

Martiñá, R. (2003). Escuela y familia: una alianza necesaria. Buenos Aires: Editorial Troquel

Razeto, A. (2016). El involucramiento de las familias en la educación de los niños. Cuatro reflexiones para fortalecer la relación entre familias y escuela. Revista Páginas de Educación. 9(2). http://www.scielo.edu.uy/pdf/pe/v9n2/v9n2a07.pdf

Robledo, P. \& García J. (2009). El entorno familiar y su influencia en el rendimiento académico de los alumnos con dificultades de aprendizaje: revisión de estudios empíricos. Aula Abierta, Vol, 37, num, 1, pp. 117-128. ISSN: 0210-2773. https://dialnet.unirioja.es/servlet/articulo?codigo=3000179

Rodríguez, D., y Guzmán, R. (2019). Rendimiento académico y factores sociofamiliares de riesgo. Variables personales que moderan su influencia. Perfiles Educativos, 41(164), 118- 134. https://doi.org/10.22201/iisue.24486167e.2019.164.58925

Ruíz de Miguel, C. (2001). Factores familiares vinculados al bajo rendimiento. Revista Complutense de Educación. 12 (1), 81-113. ISSN: 1130-2496 https://dialnet.unirioja.es/servlet/articulo?codigo $=283673$

Sheldon, S., \& Epstein, J. (2005). Involvement counts: Family and community partnerships and mathematics achievement». The Journal of Educational Research. 98(4), 196-207. https://doi.org/10.3200/JOER.98.4.196-207

Sandoval, R., Echeverría,S.,Valdéz, A. (2017). Participación de los padres en la educación: una prueba del modelo de hoover-dempsey. Perpectiva Educacional, 56(2), 139-153. doi:10.4151/07189729-Vol.56-Iss.2-Art.495

Sarmiento, P., \& Zapata, M. (2014). Modelo conceptual sobre la participación de la familia en la escuela: un estudio cualitativo en cuatro localidades del Perú. 
Avances de Investigación, 16. Lima: GRADE Group for the Analysis of Development. https://nbn-resolving.org/urn:nbn:de:0168-ssoar-56546-2

Valdés, Á. A., Pavón, M. J., \& Sánchez, P. A. (2009). Participación de los padres de alumnos de educación primaria en las actividades académicas de sus hijos. Revista Electrónica de Investigación Educativa, 11(1), 1-17. http://www.scielo.org.mx/pdf/redie/v11n1/v11n1a12.pdf

Varela, J. (2014). El habla de los padres desde preescolar puede contribuir al éxito escolar del hijo en la primaria. En Bazán, A, Vega, N (Coord). Familia- escuelacomunidad. Teorías en la práctica (115-128). Universidad Autónoma del Estado de Morelos : Juan Pablos. http://riaa.uaem.mx/xmlui/bitstream/handle/20.500.12055/224/FAMILIAESCUELA-COMUNIDAD\%20.pdf? sequence $=1 \&$ isAllowed $=\mathrm{y}$

Yurén, M. T., Cruz, M. de la, Weiss, H. B., Bouffard, S. M., Bridglall, B. L., Gordon, E. W., \& Vaca Gallegos, S. (2014). Intervención educativa en el desarrollo socioafectivo y colaboración con las familias. Perspectivas Desde El Barómetro de Las Américas, 1(1), 1-5. doi:10.1007/s13398-014-0173-7.2

\section{LCiencia}




\section{PARA CITAR EL ARTÍCULO INDEXADO}

Bustos Yépez, M. J., Navas Franco, L. E., \& Vega Buenaño, F. S. (2021). Analysis of socioeconomic factors in the participation of parents in the Ecuadorian educational $\begin{array}{llll}\text { context. Explorador } & \text { Digital, } & \text { 101-116. }\end{array}$ https://doi.org/10.33262/exploradordigital.v5i4.1910

\section{LCiencia}

El artículo que se publica es de exclusiva responsabilidad de los autores y no necesariamente reflejan el pensamiento de la Revista Explorador Digital.

El artículo queda en propiedad de la revista y, por tanto, su publicación parcial y/o total en otro medio tiene que ser autorizado por el director de la Revista Explorador Digital.
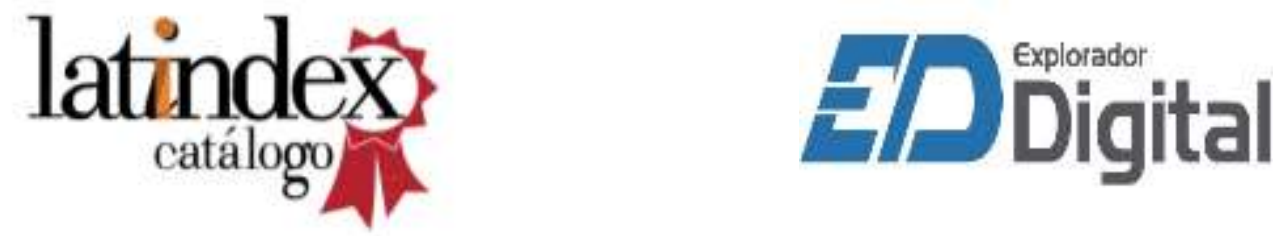